\title{
Implementasi Metode Balanced Scorecard dalam Perancangan Sistem Penilaian Kinerja Perguruan Tinggi Vokasi
}

\author{
Imam Bayhaqi \\ Sekolah Tinggi Teknologi Nasional, Jl. Petimura no. 100. Kel. Rawasari, Kota Jambi \\ Correspondence email: imambaihaqi67@gmail.com
}

\begin{abstract}
Abstrak. Balanced Scorecard (BSC) meruapakan salah satu alat yang dapat digunakan untuk mengukur kinerja suatu organisasi. Untuk meningkatkan kualitas dan mutu pendidikan di perguruan tinggi diperlukan sistem penilaian kinerja untuk mengukur kemampuan perguruan tinggi dalam menjalankan fungsinya. Dalam penelitian ini, penulis akan melakukan perancangan sistem penilaian kinerja perguruan tinggi vokasi dengan mengintegrasikan indikator yang ada pada BAN-PT, AUN-QA, MQA, dan TEQSA. Mengintegrasikan indikator bertujuan agar perguruan tinggi vokasi mampu bersaing secara nasional dan internasional. Hasil dari penelitian ini diperoleh 90 indikator yang dibagi kedalam empat perspektif BSC. Setiap indikator akan dihitung bobot nilainya dengan metode Analytic Hierarchy Process (AHP). Sistem penilaian kinerja yang telah dirancang akan digunakan perguruan tinggi vokasi untuk mengukur kinerjanya sehingga dapat diketahui perbaikan dan peningkatan yang akan dilakukan oleh perguruan tinggi tersebut agar dapat bersaing di tingkat nasional maupun internasional.
\end{abstract}

Kata kunci: Balances Scorecard; Kualitas; Analytic Hierarchy Process

\begin{abstract}
The Balanced Scorecard (BSC) is one tool that can be used to measure the performance of an organization. To improve the quality of education, a performance appraisal system is needed to measure the ability of universities to carry out their functions. In this study, the authors will design a performance appraisal system for vokasi colleges by integrating indicators in BAN-PT, AUN$Q A, M Q A$, and TEQSA. Integrating indicators aims to enable vokasi colleges to compete nationally and internationally. The results of this study obtained 90 indicators divided into four BSC perspectives. Each value will be calculated with the Analytic Hierarchy Process (AHP) method. The performance appraisal system that has been designed will be used by vokasi colleges to measure its performance so that it can be seen that improvements will be made by vokasi colleges to compete at national and international levels.
\end{abstract}

Keywords: Balances Scorecard; Quality; Analytic Hierarchy Process

\section{PENDAHULUAN}

Perguruan tinggi saat ini menghadapi tantangan yang semakin berat seiring dengan perkembangan ilmu pengetahuan dan teknologi. Hal ini membuat perguruan tinggi berlomba-lomba untuk meningkatkan kualitas dan kinerjanya. Untuk memenuhi kebutuhan pemangku kepentingan dan mencapai keseimbangan dalam pengelolaan keuangan, sumber daya organisasi, dan modal intlektual perlu adanya pengukuran kinerja di setiap unit untuk meningkatkan pengelolaan perguruan tinggi (Philbin, 2011) (Satria, dkk. 2018). Pengukuran kinerja merupakan alat untuk melakukan evaluasi internal dan penilaian strategis di perguruan tinggi (Sayed, 2013).

Proses pengukuran kinerja diperlukan untuk meningkatkan kualitas pendidikan sehingga dapat mendorong setiap perguruan tinggi untuk memperbaiki kelemahan dan memastikan kualitas pendidikan (Chen, et al. 2009). Selain itu, perguruan tinggi perlu mengembangkan cara yang efektif untuk melakukan evaluasi kinerja sebagai proses yang berkelanjutan untuk mengukur kinerja organisasi secara keseluruhan karena ini merupakan kunci untuk kelangsungan hidup perguruan tinggi (Lin, et al. 2016) (Zangoueinezhad, et al. 2011).

Politeknik merupakan perguruan tinggi yang fokus pada pendidikan vokasi profesional yang memiliki kemampuan dalam bidang ilmu pengetahuan, teknik, dan teknologi. Berdasarkan pengklarifikasian dan pemeringkatan perguruan tinggi yang dilakukan oleh Kementrian Riset Teknologi dan pendidikan tinggi pada tahun 2015 Politeknik XYZ berada pada peringkat 2.945 dari 3.293 perguruan tinggi yang ada di Indonesia (Kemenristek, 2015). Pemeringkatan berdasarkan kualitas sumber daya manusia, kualitas manajemen, kualitas kegiatan mahasiswa, kualitas penelitian, dan publikasi dosen. Politeknik XYZ memperoleh total nilai sebesar 0,31 karena hanya kualitas sumber daya manusia yang memiliki nilai. Untuk nilai kualitas manajemen, kualitas kegiatan mahasiswa, kualitas penelitian, dan publikasi dosen masih mendapat nilai nol.

Pengelola Politeknik XYZ ingin meningkatkan mutu pendidikan dan manajemen perguruan tinggi dengan melakukan perbaikan-perbaikan secara bertahap. Untuk melakukan perbaikan dan peningkatan mutu pendidikan dan manajemen di perguruan tinggi Politeknk XYZ perlu adanya kriteria dalam melakukan penilaian kinerja perguruan tinggi, sehingga dengan kriteria yang telah ditetapkan akan menjadi acuan perguruan tinggi untuk meningkatkan mutu pendidikan dan manajemen. Kriteria penilaian kinerja perguruan tinggi akan dirancangan dengan mengintegrasikan kriteria pada empat lembaga yang menjadi acuan dalam peningkatan 
mutu perguruan tinggi yaitu BAN-PT, AUN-QA, MQA, dan TEQSA.

Pengintegrasian kriteria penilaian kinerja dari empat lembaga ini bertujuan untuk mempersiapkan perguruan tinggi Politeknik XYZ untuk melakukan perbaikan berdasarkan kebutuhan dalam negeri dan luar negeri, sehingga Politeknik XYZ mampu bersaing secara nasional maupun inernasional.

Berdasarkan permasalahan yang telah dijelaskan, maka perlu dirancang suatu sistem penilaian kinerja perguruan tinggi untuk meningkatkan kinerja dan kualitas perguruan tinggi dalam dunia pendidikan, agar mampu bersaing secara nasional maupun internasional.

\section{METODE}

Berdasarkan studi literatur, penelitian terkait perancangan sistem penilaian kinerja telah dilakukan di universitas maupun politeknik untuk meningkatkan mutu pendidikan dan institusi. Penelitian tersebut membahas tentang perancangan sistem penilaian kinerja dengan mengintegrasikan beberapa standar akreditasi yang ada dibeberapa negara yang memiliki mutu pendidikan yang baik seperti Eropa, Amerika, Taiwan, dan Iran yang disesuaikan dengan kebutuhan perguruan tinggi.

Sementara itu, penelitian ini akan melakukan perancangan sistem penilaian kinerja perguruan tinggi dengan mengintegrasikan kriteria standar pendidikan yang ada di Indonesia yaitu BAN-PT dengan kriteriakriteria yang ada pada lembaga AUN-QA, MQA, dan TEQSA. Tujuan dari mengintegrasikan kriteria-kriteria ini adalah untuk meningkatkan mutu pendidikan dan sebagai persiapan Politeknik XYZ dapat bersaing secara nasional maupun internasional.

Tahapan yang dilakukan dalam penelitian ini adalah:

1. Mengintegrasikan indikator-indikator BAN-PT, AUN-QA, MQA, dan TEQSA.

2. Melakukan pemilihan indikator dengan mengisi kuisioner dengan skala likert 1-5 oleh lima orang pakar yaitu tiga orang dari Politeknik XYZ dan dua orang dari lembaga BAN-PT.

3. Kuisioner yang telah diisi oleh pakar akan dihitung rata-rata penilaian dengan tujuan mengeliminasi indikator. Metode cut off point digunakan untuk mengeliminasi. Nilai rata-rata yang kecil dari hasil cut off point akan dieliminasi.

4. Indikator terpilih akan dirancangan dalam bentuk hirarki balanced scorecard.

5. Merancang kuisioner perbandingan berpasangan bedasarkan hirarki balanced scorecard.

6. Melakukan pembobotan untuk setiap perspektif balanced scorecard, setiap variabel di dalam perspektif, dan setiap indikator di dalam variabel.
Pembobotan dilakukan dengan menggunakan kuisioner perbandingan berpasangan yang diisi oleh sepuluh orang pakar dari Politeknik XYZ. Untuk menyatukan persepsi pakar perlu dilakukan perhitungan rata-rata geometri. Nilai rata-rata goemetri akan digunakan untuk menentukan bobot setiap perspektif balanced scorecard, variabel, dan indikator penilaian kinerja.

7. Untuk mengetahui responden konsisten dalam mengisi kuisoner perbandingan berpasangan perlu dilakukan perhitungan Consistency Ratio (CR) jika nilai CR $\leq$ 0,1 maka responden konsisten dalam mengisi kuisioner dan apabila nilai $\mathrm{CR} \geq 0,1$ maka perlu dilakukan pengisian ulang oleh responden sampai nilai $\mathrm{CR} \leq 0,1$.

8. Menghitung nilai bobot keseluruhan dengan cara mengkalikan nilai bobot perspektif balanced scorecard dengan nilai bobot variabel dan nilai bobot indikator penilaian kinerja.

\section{HASIL DAN PEMBAHASAN}

Beberapa tahapan perancangan sistem penilaian kinerja perguruan tinggi yang dilakukan, yaitu melakukan pemilihan indikator, perancangan hirarki, perancangan kuisioner perbandingan berpasangan, penentuan nilai bobot, menentukan tingkat konsistensi, dan perhitungan bobot keseluruhan.

\section{Pemilihan Indikator}

Sebanyak 105 indikator yang diukur berdasarkan tingkat kepentingan terhadap peningkatan kinerja institusi dan akreditasi. Lima orang pakar telah memberikan penilaian untuk setiap indikator, dihitung rata-rata penilaian untuk menyatukan persepsi kelima pakar. Lima orang pakar yang memberikan penilaian adalah dua orang dari BAN-PT dan tiga orang dari Politeknik XYZ.

Untuk mengeliminasi, digunakan metode cut off point dengan menentukan nilai rata-rata maksimum dan minimum. Perhitungan cut off point sebagai berikut:

$$
\begin{aligned}
\text { Cut off point } & =\frac{\text { Max }+ \text { Min }}{2} \\
& =\frac{5+2,2}{2} \\
& =3,6
\end{aligned}
$$

Hasil perhitungan cut off point diperoleh nilai sebesar 3,6 yang berarti nilai rata-rata $<3,6$ yang akan dieliminasi dari indikator penilaian kinerja. Diperoleh 15 indikator yang dieliminasi dari 105 indikator sehingga diperoleh 90 indikator yang dinyatakan dapat digunakan untuk meningkatkan kinerja institusi. Indikator yang dieliminasi dapat dilihat pada Tabel 1. 
Tabel 1. Indikator Penilaian Kinerja $<3,6$

\begin{tabular}{|c|c|c|c|c|c|c|c|}
\hline \multirow{2}{*}{ No. } & \multirow{2}{*}{ Indikator Penilain Kinerja } & \multicolumn{5}{|c|}{ Penilaian Pakar } & \multirow{2}{*}{$\begin{array}{l}\text { Rata-rata } \\
\text { Penilaian }\end{array}$} \\
\hline & & 1 & 2 & 3 & 4 & 5 & \\
\hline 1. & $\begin{array}{l}\text { Meningkatkan visi, misi, budaya, dan proses pembangunan untuk memenuhi } \\
\text { kebutuhan dan kepuasan pemangku kepentingan. }\end{array}$ & 1 & 2 & 1 & 4 & 3 & 2,20 \\
\hline \multirow[t]{2}{*}{2.} & $\begin{array}{l}\text { Kebijakan dan peraturan penyedia pendidikan tinggi harus mensosialisasikan } \\
\text { praktek artikulasi, transfer kredit, dan pembebasan. }\end{array}$ & 1 & 4 & 2 & 4 & 1 & 2,40 \\
\hline & Perguruan tinggi memiliki sistem pembinaan program studi yang mencakup: & & & & & & \\
\hline \multirow[t]{2}{*}{3.} & 1) Pengembangan program studi, & 3 & 2 & 3 & 4 & 2 & 2,80 \\
\hline & 2) Penyusunan dokumen akreditasi dalam bentuk pelatihan, dana, dan informasi. & & & & & & \\
\hline 4. & $\begin{array}{l}\text { Peraturan dan mekanisme dalam pengelolaan nilai mahasiswa disampaikan kepada } \\
\text { mahasiswa dan semua dokumen dan catatan yang berkaitan dengan penilaian } \\
\text { disimpan dengan baik. }\end{array}$ & 1 & 2 & 3 & 5 & 4 & 3,00 \\
\hline 5. & $\begin{array}{l}\text { Mekanisme penetapan biaya pendidikan mahasiswa dengan mengikutsertakan } \\
\text { semua pemangku kepentingan internal. }\end{array}$ & 2 & 3 & 1 & 3 & 4 & 2,60 \\
\hline 6. & $\begin{array}{l}\text { Sistem monitoring d an evaluasi pendanaan internal untuk pemanfaatan dana yang } \\
\text { lebih efektif. transparan dan memenuhi aturan keuangan yang berlaku. }\end{array}$ & 3 & 3 & 3 & 3 & 5 & 3,40 \\
\hline 7. & $\begin{array}{l}\text { Laporan audit keuangan oleh auditor eksternal yang transparan dan dapat diakses } \\
\text { oleh semua pemangku kepentingan. }\end{array}$ & 3 & 3 & 4 & 4 & 3 & 3,40 \\
\hline
\end{tabular}

Sistem pengelolaan prasarana dan sarana berupa kebijakan, peraturan, dan pedoman/panduan untuk aspek:

8. 1) Pengembangan dan pencatatan,

2) Penetapan penggunaan,

3) Keamanan dan keselamatan penggunaan,

4) Pemeliharaan/ perbaikan/kebersihan.

9. Sistem penerimaan mahasiswa baru yang menerapkan prinsip-prinsip ekuitas.

Sistem penerimaan mahasiswa baru yang memberikan peluang dan menerima mahasiswa yang memiliki potensi akademik namun kurang mampu secara ekonomi dan/atau cacat fisik disertai bukti implementasi sistem tsb. berupa ketersediaan sarana dan prasarana penunjang

11. Sistem penerimaan mahasiswa baru menerapkan prinsip pemerataan wilayah asal mahasiswa.

12. Rasio jumlah mahasiswa yang mendaftar ulang terhadap jumlah mahasiswa yang lulus seleksi.

13. Rasio jumlah mahasiswa baru transfer terhadap jumlah mahasiswa baru bukan
transfer.

14. Instrumen dan tata cara pengukuran kepuasan mahasiswa terhadap layanan

14. kemahasiswaan

15. Layanan kepada mahasiswa dalam bidang bimbingan dan konseling, minat dan

15. bakat, pembinaan soft skills, beasiswa, dan kesehatan.

$\begin{array}{llllll}3 & 3 & 3 & 3 & 5 & \mathbf{3 , 4 0} \\ 3 & 3 & 2 & 4 & 2 & \mathbf{2 , 8 0} \\ 3 & 2 & 2 & 2 & 5 & \mathbf{2 , 8 0} \\ 3 & 2 & 3 & 2 & 5 & \mathbf{3 , 0 0} \\ 3 & 2 & 3 & 4 & 5 & \mathbf{3 , 4 0} \\ 3 & 2 & 3 & 4 & 5 & \mathbf{3 , 4 0} \\ 3 & 2 & 3 & 3 & 5 & \mathbf{3 , 2 0} \\ 3 & 2 & 4 & 2 & 5 & \mathbf{3 , 2 0}\end{array}$

\section{Perancangan Hirarki}

Perancangan hirarki penilaian kinerja terdiri dari perspektif balanced scorecard (Saaty, 2008), variabel penilaian kinerja, dan indikator penilaian kinerja. Hirarki penilaian kinerja institusi terbagi menjadi empat level. Level 0 merupakan tujuan dari penilaian kinerja institusi, level 1 merupakan perspektif balanced scorecard, level 2 merupakan variabel penilaian kinerja, dan level 3 merupakan indikator yang digunakan untuk meningkatkan kinerja institusi. Hirarki penilaian kinerja untuk perspektif keuangan dapat dilihat pada Gambar 1.

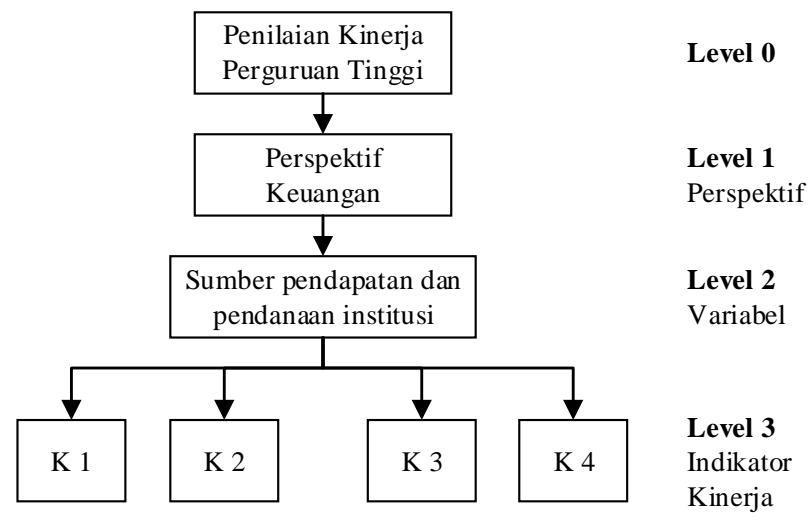

Gambar 1. Hirarki Perspektif Keuangan

Perspektif pelanggan/mahasiswa terdiri dari empat variabel dengan 12 indikator keseluruhan, perspektif proses internal terdiri dari 9 variabel dengan 52 indikator keseluruhan, dan perspektif pembelajaran dan pertumbuhan terdiri dari empat variabel dengan 22 indikator. Hasil perancangan hirarki diperoleh empat 
perspektif penilaian kinerja dengan total 18 variabel dan 90 indikator penilaian kinerja perguruan tinggi.

\section{Perancangan Kuisioner}

Kuisioner perbandingan berpasangan dirancang berdasarkan hirarki penilaian kinerja. Perbandingan dilakukan untuk setiap perspektif balanced scorecard, variabel yang ada dalam perspektif balanced scorecard, dan indikator yang ada dalam variabel. Perancangan kuisioner perbandingan berpasangan perspektif balanced scorecard dapat dilihat pada Tabel 2 (Kaplan dan Norton, 1992, 2001).

Tabel 2. Kuisioner Perbandingan Berpasangan Perspektif

\begin{tabular}{|c|c|c|c|c|c|c|c|c|c|c|c|c|c|c|c|c|c|c|}
\hline Perspektif (A) & 9 & 8 & 7 & 6 & 5 & 4 & 3 & 2 & 1 & 2 & 3 & 4 & 5 & 6 & 7 & 8 & 9 & Perspektif (B) \\
\hline Proses Internal (PI) & & & & & & & & & & & & & & & & & & $\begin{array}{l}\text { Pelanggan/Mahasiswa } \\
\text { (Pel) }\end{array}$ \\
\hline Proses Internal (PI) & & & & & & & & & & & & & & & & & & Keuangan (Keu.) \\
\hline Proses Internal (PI) & & & & & & & & & & & & & & & & & & $\begin{array}{l}\text { Pembelajaran dan } \\
\text { Pertumbuhan (PP) }\end{array}$ \\
\hline Pelanggan/Mahasiswa (Pel) & & & & & & & & & & & & & & & & & & Keuangan (Keu.) \\
\hline Pelanggan/Mahasiswa (Pel.) & & & & & & & & & & & & & & & & & & $\begin{array}{l}\text { Pembelajaran dan } \\
\text { Pertumbuhan (PP) }\end{array}$ \\
\hline Keuangan (Keu.) & & & & & & & & & & & & & & & & & & $\begin{array}{l}\text { Pembelajaran dan } \\
\text { Pertumbuhan (PP) }\end{array}$ \\
\hline
\end{tabular}

Perspektif balanced scorecard yang digunakan dalam perancangan penilaian kinerja perguruan tinggi terdiri dari perspektif keuangan (Keu.), perspektif pelanggan/mahasiswa (Pel.), perspektif proses internal (PI), dan perspektif pembelajaran dan pertumbuhan (PP). Pengisian kuisioner dengan membandingkan antara Perspektif (A) dengan Perspektif (B). Skala bagian kiri digunakan jika Perspektif (A) mempunyai tingkat pengaruh lebih besar dibandingkatn Perspektif (B) dan sebaliknya, skala bagian kanan digunakan jika Perspektif (B) mempunyai tingkat pengaruh lebih besar dibandingkatn Perspektif (A).

\section{Penentuan Nilai Bobot}

Penentuan nilai bobot diperoleh dari penilaian yang telah dilakukan oleh sepuluh orang pakar dari Politeknik $\mathrm{XYZ}$ dengan mengisi kuisioner perbandingan berpasangan. Sepuluh orang pakar yang menjadi responden adalah Ketua, Pembantu Ketua 1 dan 2, Kepala Mutu, Lembaga Mutu Prodi, Kepala Proses Belajar Mengajar, dan Ketua Prodi.

Penilaian dilakukan dengan menggunakan kuisioner perbandingan berpasangan pada Tabel 2 sesuai ketentuan. Hasil penilaian yang telah dilakukan oleh sepuluh orang pakar kemudian dihitung rata-rata geometri untuk menyatukan persepsi penilaian yang dilakukan oleh sepuluh orang pakar. Hasil perhitungan rata-rata geometri dapat dilihat pada Tabel 3.

Tabel 3. Hasil Penilaian Perspektif Balanced Scorecard

\begin{tabular}{|c|c|c|c|c|c|c|c|c|c|c|c|c|}
\hline \multirow{2}{*}{$\begin{array}{c}\text { Perspektif } \\
\text { Pembanding }\end{array}$} & \multirow{2}{*}{$\begin{array}{c}\text { Perspektif } \\
\text { yang Dibandingkan }\end{array}$} & \multicolumn{10}{|c|}{ Penilaian Pakar } & \multirow{2}{*}{$\begin{array}{l}\text { Rata-rata } \\
\text { Geometri }\end{array}$} \\
\hline & & 1 & 2 & 3 & 4 & 5 & 6 & 7 & 8 & 9 & 10 & \\
\hline PI & Pel. & $1 / 3$ & $1 / 2$ & 3 & 1 & $1 / 3$ & 2 & $1 / 3$ & 3 & 5 & 1 & 1,052 \\
\hline PI & Keu. & $1 / 5$ & $1 / 4$ & $1 / 3$ & $1 / 4$ & 1 & 1 & $1 / 2$ & 1 & 3 & $1 / 3$ & 0,539 \\
\hline PI & PP & 3 & 3 & 4 & 4 & 3 & 3 & 2 & 3 & 4 & 3 & 3,140 \\
\hline Pel. & Keu. & $1 / 5$ & $1 / 3$ & $1 / 2$ & $1 / 2$ & 1 & $1 / 3$ & 1 & 1 & 2 & 1 & 0,638 \\
\hline Pel. & $\mathrm{PP}$ & 3 & 2 & 3 & 3 & 4 & 3 & 4 & 4 & 2 & 4 & 3,104 \\
\hline Keu. & PP & 7 & 5 & 6 & 4 & 5 & 3 & 2 & 2 & 2 & 4 & 3,635 \\
\hline
\end{tabular}

Perhitungan rata-rata geometri menggunakan persamaan berikut:

Rata-rata Geometri $=\sqrt[n]{X_{1} x \ldots x X_{n}}$

$$
\begin{aligned}
\text { PI }- \text { Pel. } & =\sqrt[10]{\frac{1}{3} x \frac{1}{2} \times 3 \times 1 \times \frac{1}{3} \times 2 \times \frac{1}{3} \times 3 \times 5 \times 1} \\
& =1,052
\end{aligned}
$$

Hasil rata-rata geometri digunakan untuk menghitung bobot setiap perspektif, variabel, dan indikator. Selanjutnya akan dilakukan matriks perbandingan berpasangan menggunakan hasil rata-rata geometri. Matriks perbandingan berpasangan untuk perspektif balanced scorecard dapat dilihat pada Tabel 4.

Tabel 4. Matriks Perspektif Balanced Scorecard

\begin{tabular}{ccccc}
\hline Perspektif & PI & Pel. & Keu. & PP \\
\hline PI & 1 & 1,052 & 0,539 & 3,140 \\
Pel. & 0,950 & 1 & 0,638 & 3,104 \\
Keu. & 1,854 & 1,568 & 1 & 3,635 \\
PP & 0,318 & 0,322 & 0,275 & 1 \\
TOTAL & 4,123 & 3,943 & 2,452 & 10,880 \\
\hline
\end{tabular}

Hasil rata-rata geometri pada Tabel 5 dimasukkan kedalam matriks perbandingan berpasangan disebelah kanan atas. Untuk membandingkan dua hal yang sama diberi nilai 1, misalkan Proses Internal (PI) 
dibandingkan dengan Proses Internal (PI). Nilai Proses Internal (PI) dibandingkan dengan Pelanggan/Mahasiswa (Pel.) diperoleh nilai 1,052 dari rata-rata geometri, sebaliknya nilai Pelanggan/Mahasiswa (Pel.) dibandingkan dengan Proses Internal (PI) diperoleh nilai 0,950 atau 1 dibagi 1,052. Hasil matriks perbandingan berpasangan perspektif balanced scorecard digunakan untuk menghitung bobot setiap perspektif balanced scorecard, hasil perhitungan bobot dapat dilihat pada Tabel 5.

Tabel 5. Hasil Perhitungan Bobot Perspektif

\begin{tabular}{cccccc}
\hline Perspektif & PI & Pel. & Keu. & PP & Bobot \\
\hline PI & 0,243 & 0,267 & 0,220 & 0,289 & 0,255 \\
Pel. & 0,230 & 0,254 & 0,260 & 0,285 & 0,257 \\
Keu. & 0,450 & 0,398 & 0,408 & 0,334 & 0,397 \\
PP & 0,077 & 0,082 & 0,112 & 0,092 & 0,091 \\
\hline
\end{tabular}

Sebelum mendapatkan nilai bobot lokal, perlu dilakukan normalisasi matriks dengan menggunakan persamaan (3) sebagai berikut:

$X_{P I, P e l .}^{\prime}=\frac{1,052}{3,943}$

$X_{\text {PI,Pel. }}^{\prime}=0,267$

Hasil perhitungan normalisasi matriks digunakan untuk menghitung bobot lokal dengan menggunakan persamaan (4) sebagai berikut:

$B_{P I}=\frac{0,243+0,267+0,220+0,289}{4}$

$B_{P I}=0,255$

Berdasarkan hasil perhitungan pembobotan perspektif balanced scorecard dapat diketahui bahwa perspektif keuangan (Keu.) dengan bobot 0,397 menjadi perioritas utama Politeknik XYZ untuk meningkatkan kinerja isntitusi, hal ini disebabkan perguruan tinggi memerlukan dana yang cukup untuk mengembangkan institusi, upah karyawan, dan tenaga pengajar. Perspektif pelanggan/mahasiswa (Pel.) mendapat bobot 0,257, ini merupakan prioritas kedua institusi dalam menjalankan pendidikan tinggi dengan memberikan pelayanan yang baik ke mahasiswa, meningkatkan kualitas mahasiswa, meningkatkan kelulusan mahasiswa, dan meningkatkan indeks prestasi mahasiswa. Perspektif proses internal (PI) mendapatkan bobot 0,255 dalam meningkatkan kinerja institusi seperti persiapan manajemen yang baik dengan memiliki visi, misi, dan sasaran capaian institusi, sistem tata pamong, sistem penjamin mutu, memiliki sumber daya manusia yang berkualitas dalam pendidikan, dan kebijakan-kebijakan pimpinan terhadap kemajuan institusi. Perspektif pembelajaran dan pertumbuhan (PP) memperoleh bobot 0,091 untuk meningkatkan kinerja institusi seperti meningkatkan kompetensi tenaga kerja, meningkatkan hasil karya dosen dan mahasiswa, merancang sistem informasi yang mudah diakses sebagai pendukung kegiatan belajar, dan melakukan kegitan kerja sama dengan institusi dan instansi yang ada dalam negeri maupun luar negeri.

\section{Menentukan Tingkat Konsistensi}

Penilaian bobot yang dilakukan oleh pakar perlu diuji tingkat konsistensinya dalam mengisi kuisioner perbandingan berpasangan. Untuk mengetahui para pakar konsisten dalam mengisi kuisoner perbandingan berpasangan perlu dilakukan perhitungan Consistency Ratio (CR), jika nilai CR $\leq 0,1$ maka para pakar konsisten dalam mengisi kuisioner dan apabila nilai $C R \geq 0,1$ maka perlu dilakukan pengisian ulang oleh pakar sampai nilai $\mathrm{CR} \leq 0,1$. Hasil perhitungan $\mathrm{CR}$ untuk perspektif balanced scorecard dapat dilihat pada Tabel 6 .

Tabel 6. Consistency Ratio (CR) Perspektif

\begin{tabular}{lllllll}
\hline $\begin{array}{l}\text { Perspekti } \\
\mathrm{f}\end{array}$ & WSF & CF & $\overline{C F}$ & CI & RI & CR \\
\hline PI & 1,025 & 4,026 & & & & \\
Pel. & 1,034 & 4,019 & 4,02 & 0,007 & 0, & 0,008 \\
Keu. & 1,603 & 4,034 & 2 & 4 & 9 & 3 \\
PP & 0,364 & 4,011 & & & & \\
\hline
\end{tabular}

Untuk mengetahui para pakar memberi penilaian dengan konsisten perlu dilakukan beberapa tahap, yaitu perhitungan Weight Sum Factor (WSF) dengan menggunakan persamaan (5) sebagai berikut:

$$
\begin{aligned}
W S F_{P I}= & (1 \times 0,255)+(1,052 \times 0,257)+(0,539 \times 0,397) \\
& +(3,14 \times 0,091) \quad \ldots(5) \\
= & 1,025
\end{aligned}
$$

Perhitungan Consistency Factor (CF) dengan menggunakan persamaan (6) sebagai berikut:

$$
\begin{aligned}
C F_{P I} & =\frac{1,025}{0,255} \\
& =4,026 \\
\overline{C F} & =\frac{4,026+4,019+4,038+4,011}{4} \\
& =4,022
\end{aligned}
$$

Perhitungan Consistency Index (CI) dengan menggunakan persamaan (7) sebagai berikut:

$$
\begin{aligned}
C I & =\frac{4,022-4}{4-1} \\
& =0,0074
\end{aligned}
$$

Tabel 7. Ratio Index

\begin{tabular}{ccccccccccc}
\hline$m$ & 1 & 2 & 3 & 4 & 5 & 6 & 7 & 8 & 9 & 10 \\
\hline$R I$ & 0 & 0 & 0,58 & 0,9 & 1,12 & 1,24 & 1,32 & 1,41 & 1,45 & 1,49 \\
\hline
\end{tabular}

Penentuan Index Ratio (RI) dengan menggunakan Tabel 7. Nilai index ratio dengan jumlah kriteria empat adalah 0,9. Untuk menghitung Consistency Ratio (CR) dengan menggunakan persamaan (8) sebagai berikut: 


$$
\begin{aligned}
C R & =\frac{0,0074}{0,9} \\
& =0,0083
\end{aligned}
$$

Berdasarkan perhitungan, diperoleh nilai CR sebesar 0,0083. Hasil ini menunjukkan bahwa para pakar konsisten dalam memberikan penilaian bobot dalam melakukan perbandingan berpasangan karena nilai $\mathrm{CR}$ yang diperoleh $0,0083 \leq 0,1$.

\section{Nilai Bobot Keseluruhan}

Setelah melakukan tahapan dalam menghitung bobot setiap perspektif balanced scorecard, variabel, dan indikator tahap selanjutnya adalah menghitung bobot keseluruhan untuk mendapatkan bobot setiap indikator kinerja dengan cara mengalikan bobot perspektif dengan bobot variabel dan bobot indikator. Bobot keseluruhan untuk perspektif keuangan dapat dilihat pada Tabel 8.

Tabel 8. Bobot Keseluruhan Perspektif Keuangan

\begin{tabular}{lllllll}
\hline Perspektif & Variabel & Kode Indikator & Bobot Perspektif & Bobot Variabel & Bobot Indikator & Total Bobot \\
\hline \multirow{3}{*}{ Keuangan } & Sumber & K 1 & & & 0,307 & 0,122 \\
& Pendapatan dan & K 2 & 0,397 & 1 & 0,129 & 0,051 \\
& Pendanaan & K 3 & & & 0,276 & 0,110 \\
& Institusi & K 4 & & 0,288 & 0,114 \\
\hline
\end{tabular}

Perspektif keuangan terdiri dari satu variabel yaitu sumber pendapatan dan pendanaan institusi, sehingga nilai bobot variabel bernilai 1 . Berdasarkan perhitungan bobot keseluruhan diperoleh persentase penggunaan dana perguruan tinggi yang berasal dari mahasiswa (K1) sebesar 0,122, indikator ini merupakan prioritas utama institusi dalam penilaian kinerja, indikator selanjutnya adalah penggunaan dana untuk operasional (K4) dengan bobot 0,114 , dana penelitian dalam tiga tahun terakhir (K3) dengan bobot 0,110, dan dana yang diperoleh dalam rangka pelayanan dan pengabdian kepada masyarakat dalam tiga tahun terakhir (K2) dengan bobot 0,051. Untuk penilaian bobot keseluruhan perspektif pelanggan/mahasiswa dapat dilihat pada Tabel 9.

\begin{tabular}{|c|c|c|c|c|c|c|}
\hline Perspektif & Variabel & $\begin{array}{c}\text { Kode } \\
\text { Indikator }\end{array}$ & $\begin{array}{c}\text { Bobot } \\
\text { Perspektif }\end{array}$ & $\begin{array}{c}\text { Bobot } \\
\text { Variabel }\end{array}$ & $\begin{array}{c}\text { Bobot } \\
\text { Indikator }\end{array}$ & $\begin{array}{c}\text { Total } \\
\text { Bobot }\end{array}$ \\
\hline \multirow{12}{*}{$\begin{array}{l}\text { Pelanggan } \\
\text { / } \\
\text { Mahasiswa }\end{array}$} & $\begin{array}{c}\text { Tingkat kelulusan calon mahasiswa yang ikut } \\
\text { seleksi }\end{array}$ & KCM 1 & \multirow{9}{*}{0,257} & 0,115 & 1 & 0,0296 \\
\hline & & PKP 1 & & \multirow{5}{*}{0,224} & 0,229 & 0,0132 \\
\hline & Peningkatan kualitas pelayanan dan prestasi & PKP 2 & & & 0,204 & 0,0118 \\
\hline & mahasiswa & PKP 3 & & & 0,278 & 0,0160 \\
\hline & & PKP 4 & & & 0,289 & 0,0167 \\
\hline & & PKM 1 & & & 0,128 & 0,0051 \\
\hline & \multirow{3}{*}{ Penilaian kelulusan mahasiswa } & PKM 2 & & \multirow{3}{*}{0,154} & 0,327 & 0,0130 \\
\hline & & PKM 3 & & & 0,339 & 0,0135 \\
\hline & & PKM 4 & & & 0,206 & 0,0082 \\
\hline & Melakukan studi pelacakan, evaluasi, dan & SP 1 & \multirow{3}{*}{0,257} & \multirow{3}{*}{0,506} & 0,3095 & 0,0403 \\
\hline & partisipasi alumni untuk mendukung pengembangan & SP 2 & & & 0,3095 & 0,0403 \\
\hline & Institusi & SP 3 & & & 0,3809 & 0,0496 \\
\hline
\end{tabular}

Tabel 9. Bobot Keseluruhan Perspektif Pelanggan/Mahasiswa

Perspektif pelanggan/mahasiswa terdiri dari empat variabel dengan nilai bobot varibel tertinggi 0,506 pada variabel studi pelacakan, evaluasi, dan partisipasi alumni dalam pengembangan institusi, untuk nilai bobot variabel peningkatan kualitas pelayanan dan prestasi mahasiswa sebesar 0,224, variabel penilaian kelulusan mahasiswa sebesar 0,154, dan variabel tingkat kelulusan calon mahasiswa yang ikut seleksi sebesar 0,115. Berdasarkan perhitungan bobot keseluruhan, indikator pertisipasi alumni dalam mendukung pengembangan perguruan tinggi (SP3) dengan bobot 0,0496, rasio alumni dalam memberikan respon studi pelacakan dalam lima tahun terakhir (SP2) dengan bobot 0,0403, dan sistem evaluasi lulusan yang efektif (SP1) dengan bobot 0,0403 menjadi prioritas institusi dalam melakukan penilaian kinerja untuk perspektif pelanggan/mahasiswa diikuti dengan indikator yang lainnya. Penilaian bobot keseluruhan untuk persektif proses internal dapat dilihat padat Tabel 10 . 
Tabel 10. Bobot Keseluruhan Perspektif Proses Internal

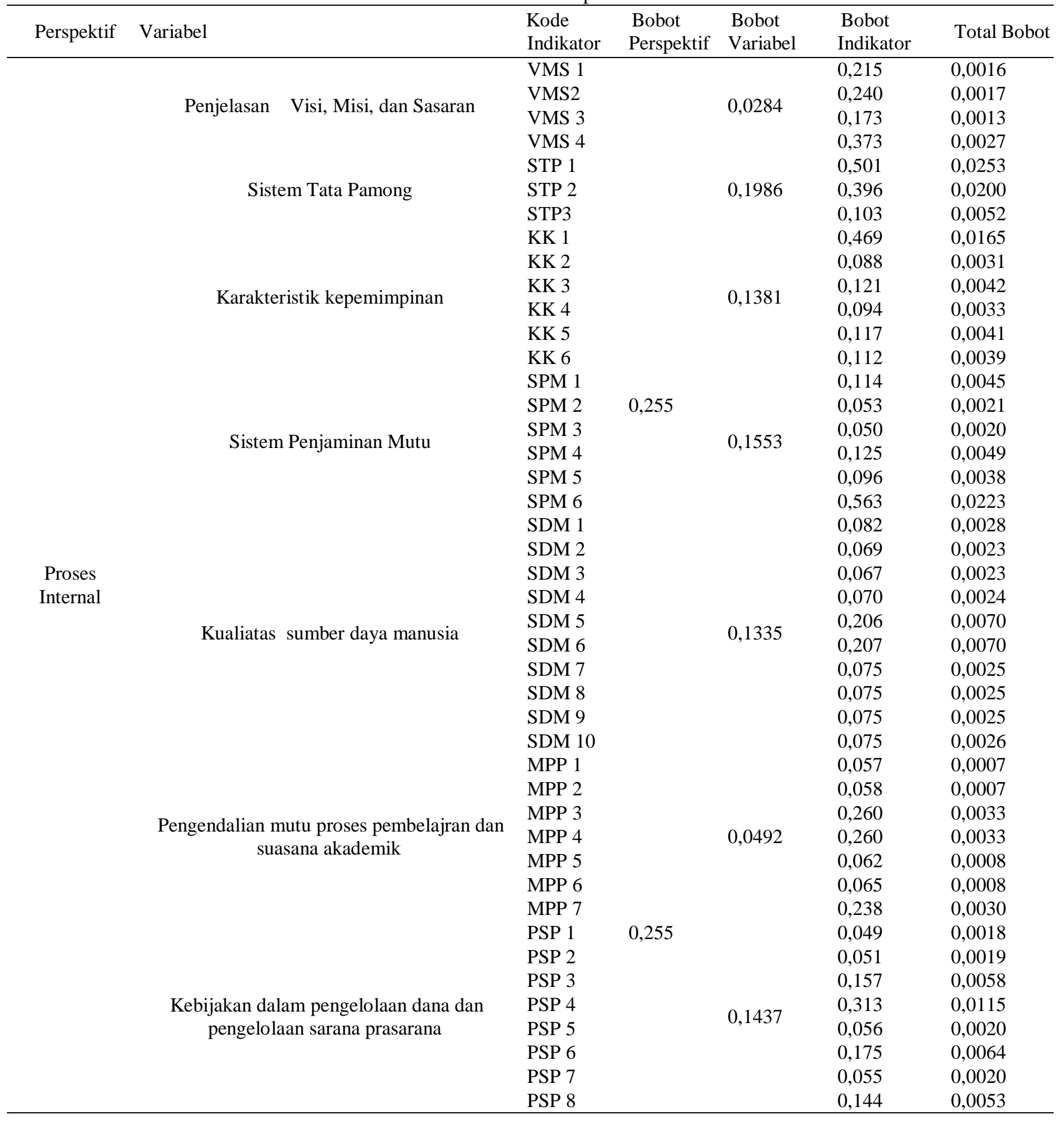

Perspektif proses internal terdiri dari sembilan variabel. Variabel yang mendapatkan bobot tertinggi adalah sistem tata pamong dengan bobot sebesar 0,1986, sistem penjamin mutu dengan bobot sebesar 0,1553 , dan kebijakan dalam pengelolaan dana dan sarana prasarana dengan bobot sebesar 0,1437. Total indikator dalam perspektif proses internal terdiri dari 52 indikator. Indikator yang menjadi prioritas penilaian kinerja dalam perspektif proses internal adalah indikator perguruan tinggi memiliki tata pamong yang terlaksana secara konsisten (STP2) dengan bobot indikator 0,0253, status akreditasi BAN-PT untuk seluruh program studi dalam perguruan tinggi (SPM6) dengan bobot indikator 0,0223, kelengkapan dan keefektifan struktur organisasi yang disesuaikan dengan kebutuhan penyelenggaraan dan pengembangan perguruan tinggi yang bermutu (STP2) dengan bobot indikator 0,0200 , dan karateristik kepemimpinan yang efektif dalam kepemimpinan operasional, kepemimpinan organisasi, dan kepemimpinan publik (KK1) dengan bobot indikator 0,0165 . Penilaian bobot keseluruhan untuk persektif pembelajaran dan pertumbuhan dapat dilihat Tabel 11. 
Tabel 11. Bobot Keseluruhan Perspektif Pembelajaran dan Pertumbuhan

\begin{tabular}{|c|c|c|c|c|c|c|}
\hline Perspektif & Variabel & $\begin{array}{c}\text { Kode } \\
\text { Indikator }\end{array}$ & $\begin{array}{c}\text { Bobot } \\
\text { Perspektif }\end{array}$ & $\begin{array}{c}\text { Bobot } \\
\text { Variabel }\end{array}$ & $\begin{array}{c}\text { Bobot } \\
\text { Indikator }\end{array}$ & Total Bobot \\
\hline \multirow{22}{*}{$\begin{array}{l}\text { Pembelajaran } \\
\text { dan } \\
\text { Pertumbuhan }\end{array}$} & \multirow{4}{*}{ Peningkatan kompetensi tenaga kerja } & KTK 1 & \multirow{3}{*}{0,0908} & \multirow{3}{*}{0,435} & 0,387 & 0,0153 \\
\hline & & KTK 2 & & & 0,309 & 0,0122 \\
\hline & & KTK 3 & & & 0,304 & 0,0120 \\
\hline & & SI 1 & & \multirow{8}{*}{0,130} & 0,160 & 0,0019 \\
\hline & \multirow{6}{*}{$\begin{array}{c}\text { Sistem informasi sebagai pendukung dalam } \\
\text { pengembangan pembelajaran dan } \\
\text { pertumbuhan }\end{array}$} & SI 2 & & & 0,116 & 0,0014 \\
\hline & & SI 3 & & & 0,123 & 0,0014 \\
\hline & & SI 4 & & & 0,119 & 0,0014 \\
\hline & & SI 5 & & & 0,127 & 0,0015 \\
\hline & & SI 6 & & & 0,120 & 0,0014 \\
\hline & & SI 7 & & & 0,137 & 0,0016 \\
\hline & \multirow{7}{*}{$\begin{array}{c}\text { Hasil karya dosen dan mahasiswa dalam } \\
\text { dunia pendidikan }\end{array}$} & SI 8 & & & 0,097 & 0,0011 \\
\hline & & KDM 1 & & \multirow{6}{*}{0,288} & 0,202 & 0,0053 \\
\hline & & KDM 2 & 0,0908 & & 0,139 & 0,0036 \\
\hline & & KDM 3 & & & 0,183 & 0,0048 \\
\hline & & KDM 4 & & & 0,212 & 0,0055 \\
\hline & & KDM 5 & & & 0,119 & 0,0031 \\
\hline & & KDM 6 & & & 0,145 & 0,0038 \\
\hline & \multirow{5}{*}{$\begin{array}{l}\text { Kegiatan kerja sama dengan instansi yang } \\
\text { berkaiatan dengan bidang keahlian }\end{array}$} & KKS 1 & & \multirow{5}{*}{0,148} & 0,200 & 0,0027 \\
\hline & & KKS 2 & & & 0,200 & 0,0027 \\
\hline & & KKS 3 & & & 0,200 & 0,0027 \\
\hline & & KKS 4 & & & 0,201 & 0,0027 \\
\hline & & KKS 5 & & & 0,200 & 0,0027 \\
\hline
\end{tabular}

Perspektif pembelajaran dan pertumbuhan terdiri dari empat variabel penilaian kinerja. Variabel peningkatan kompetensi tenaga kerja mendapat nilai bobot sebesar 0,435 , hasil karya dosen dan mahasiswa dalam dunia pendidikan dengan bobot sebesar 0,288, kegiatan kerja sama dengan instansi yang berkaitan dengan bidang keahlian dengan bobot 0,148 , dan sistem informasi sebagai pendukung dalam pengembangan pembelajaran dan pertumbuhan dengan bobot 0,130. Total indikator dalam perspektif pembelajaran dan pertumbuhan terdiri dari 22 indikator. Indikator yang menjadi prioritas adalah indikator upaya perguruan tinggi dalam meningkatkan kualifikasi dan kompetensi tenaga kependidikatan (KTK1) dengan bobot sebesar 0,0153, pelaksanaan survei kepuasan dosen, pustakawan, laboran, teknisi, tenaga administrasi, dan tenaga pendukung terhadap sistem pengelolaan sumber daya manusia (KTK2) dengan bobot 0,0122, dan pemanfaatan hasil survei kepuasan dosen, pustakawan, laboran, teknisi, tenaga administrasi, dan tenaga pendukung terhadap sistem pengelolaan sumber daya manusia (KTK3) dengan bobot 0,120 .

\section{Pembahasan}

Perancangan sistem penilaian kinerja perguruan tinggi digunakan untuk meningkatkan kinerja di Politeknik XYZ. Berdasarkan penilaian yang dilakukan oleh Kemenristekdikti untuk kualitas sumber daya manusia yang ada di Politeknik XYZ mendapat nilai 0,31, hal ini dikarenakan belum adanya dosen yang berpendidikan S3. Dosen saat ini berjumlah 32 orang dengan pendidikan S2 berjumlah 21 orang dan S1 berjumlah 11 orang. Penilaian untuk kualitas manajemen tidak mendapatkan nilai atau nol, penilaian ini berdasarkan akreditasi untuk semua program studi masih mendapat nilai $\mathrm{C}$ dan belum dilakukannya akreditasi untuk institusi. Kualitas kegiatan mahasiswa tidak mendapat nilai atau nol karena dalam perlombaan Pekan Ilmiah Mahasiswa Nasional (PIMNAS) dan internasional belum diperoleh, baik yang diadakan oleh Kemenristekdikti maupun non Kemenristekdikti. Kualitas penelitian dan publikasi mendapat nilai nol karena belum ada penelitian dan publikasi yang dilakukan oleh dosen. Dari keempat penilaian ini yang mendapatkan nilai hanya kualitas sumber daya manusia, sehingga total nilai yang diperoleh 0,31 . Dengan nilai ini Politeknik XYZ berada pada peringkat peringkat ke 2.945 dari 3.293 perguruan tinggi di Indonesia.

Perancangan sistem penilaian kinerja untuk perguruan tinggi dengan menggunakan model balanced scorecard yang terdiri dari empat perspektif diperoleh 18 variabel dan 90 indikator penilaian kinerja perguruan tinggi. Dari keempat perspektif balanced scorecard, perspektif keuangan yang menjadi prioritas utama institusi dalam penilaian kinerja, selanjutnya perspektif pelanggan/Mahasiwa, perspektif proses internal, dan perspektif pembelajaran dan pertumbuhan.

Perspektif keuangan menjadi prioritas institusi, karena saat ini sumber pendapatan utama berasal dari dana mahasiswa sehingga institusi ingin menekan pendapatan dari dana mahasiswa dengan mencari dana bantuan seperti dana hibah dari kementrian pendidikan dan kebudayaan, dana hibah dari pemerintah daerah, dan bantuan dana dari perusahaan.

Perspektif pelanggan/mahasiswa menjadi fokus kedua dari institusi dalam penilaian kinerja. Institusi menginginkan peningkatan kualitas layanan kepada mahasiswa untuk membantu dalam menjalankan 
perkuliahan dengan baik sehingga menghasilkan lulusan yang tepat waktu dan nilai IPK diatas 3,25 dengan ini mahasiswa mampu bersaing untuk mendapatkan pekerjaan yang sesuai dengan bidang keilmuannya.

Perspektif proses internal menjadi fokus ketiga dari institusi dalam penilaian kinerja. Visi, misi, dan sasaran menjadi panduan dalam menjalankan pendidikan tinggi sehingga institusi memiliki tujuan yang jelas. Untuk mencapai itu, institusi perlu mempersiapkan sistem tata pamong yang dapat berjalan secara konsisten, mempersiapkan sistem penjamin mutu, mempersiapkan sumber daya manusia yang berkualitas, pengendalian mutu proses pembelajaran, adanya kebijakan-kebijakan dalam pengelolaan dana, melakukan penelitian, melakukan kegiatan pelayanan pengabdian kepada masyarakat, dan dalam penerimaan mahasiswa baru.

Perspektif pembelajaran dan pertumbuhan menjadi prioritas terakhir yang dipilih institusi untuk penilaian kinerja. Dalam perspektif ini, institusi perlu melakukan peningkatan kompetensi tenaga kerja dengan memberikan kesempatan belajar atau mengikuti pelatihan yang difasilitasi oleh institusi, mempersiapkan sistem informasi sebagai pendukung dalam pembelajaran, memfasilitasi dosen dalam melakukan penelitian, dan melakukan kerjasama dengan institusi dan instansi yang berkaitan dengan bidang keahlian (Dian, 2018).

Sistem penilaian kinerja yang telah dirancang untuk perguruan tinggi dengan mengintegrasikan indikator kinerja dari BAN-PT, AUN-QA, MQA, dan TEQSA dalam model balanced scorecard dapat membantu pimpinan dalam memonitoring kinerja institusi sehingga dapat disusun strategi untuk meningkatkan kemampuan institusI (Al-Hosaini, et al. 2015), sehingga institusi mampu bersaing dengan perguruan tinggi nasional maupun internasional.

\section{SIMPULAN}

Berdasarkan hasil penelitian yang telah dilakukan, maka diperoleh kesimpulan antara lain perancangan sistem penilaian kinerja perguruan tinggi telah dilakukan pada Politeknik XYZ. Perancangan ini mengintegrasikan indikator kinerja BAN-PT, AUN-QA, MQA, dan TEQSA dalam model balanced scorecard dengan memberikan nilai bobot untuk setiap indikator penilaian kinerja dengan menggunakan metode Analytic Hierarchy Process (AHP).

Indikator penilain kinerja terbagi menjadi empat perspektif yaitu perspektif keuangan yang terdiri dari indikator-indikator perolehan dana yang digunakan oleh institusi, perspektif pelanggan/mahasiswa yang terdiri dari indikator-indikator peningkatan pelayan terhadap mahasiswa dan peningkatan kemampuan akademik mahasiswa, perspektif proses internal yang terdiri dari indikator-indikator peningkatan kemampuan manajemen institusi dalam menjalankan pendidikan tinggi, dan perspektif pembelajaran dan pertumbuhan yang terdiri dari indikator-indikator untuk meningkatkan kompetensi dosen, penelitian dosen, sistem informasi sebagai pendukung proses belajar, dan kegiatan kerjasama antar institusi dan instansi.

\section{DAFTAR PUSTAKA}

A.Zangoueinezhad and A. Moshabaki, "Measuring university performance using a knowledge-based balanced scorecard," Int. J. Product. Perform. Manag., vol. 60, no. 8, pp. 824-843, 2011.

Abadi, Satria. dkk, Model Pengukuran Kinerja Perguruan Tinggi Swasta Di Kabupaten Pringsewu Menggunakan Metode Balanced Scorecard dan Fuzzy Multiple Attribute Decision Making," Seminar Nasional Teknologi Informasi dan Multimedia. ISSN : 2302-3805. 2018.

Kementerian Riset Teknologi Dan Pendidikan Tinggi Republik Indonesia, "SK Klasifikasi dan Pemeringkatan Perguruan Tinggi di Indonesia Tahun 2015," 2015.

M. H. Lin, J. Hu, M. L. Tseng, A. S. F. Chiu, and C. Lin, "Sustainable development in technological and vocational higher education: Balanced scorecard measures with uncertainty," J. Clean. Prod., no. 2014, 2016.

N. Sayed, "Ratify, reject or revise: balanced scorecard and universities," Int. J. Educ. Manag., vol. 27, no. 3, pp. 203-220, 2013.

Permana, Dian J. "Perancangan Sistem Pengukuran Kinerja Perguruan Tinggi Melalui Metode Academic Scorecard." JPIT, Vol. 03, No 01. 2018.

R. S. Kaplan and D. P. Norton, "Transforming the BSC from performance measurement to strategic management: part I," Account. Horizons, vol. 15, no. 1, pp. 87-104, 2001.

R. S. Kaplan and D. P. Norton, "The Balanced Scorecard - Measures that Drive Performance The Balanced Scorecard-Measures that Drive Performance," Harv. Bus. Rev., pp. 71-9, 1992.

S. P. Philbin, "Design and implementation of the Balanced Scorecard at a university institute," Meas. Bus. Excell., vol. 15, no. 3, pp. 34-45, 2011.

S.-H. Chen, H.-H. Wang, and K.-J. Yang, "Establishment and application of performance measure indicators for universities," TQM J., vol. 21, no. 3, pp. 220235, 2009.

T. L. Saaty, "Decision making with the analytic hierarchy process," Int. J. Serv. Sci., vol. 1, no. 1, p. 83, 2008. 